\title{
Lip and Oral Cavity Cancer cN2c TNM Finding v8
}

National Cancer Institute

\section{Source}

National Cancer Institute. Lip and Oral Cavity Cancer cN2c TNM Finding v8. NCI

Thesaurus. Code C132716.

Lip and oral cavity cancer with metastases in bilateral or contralateral lymph nodes, none larger than $6 \mathrm{~cm}$ in greatest dimension, and ENE(-). (from AJCC 8th Ed.) 